\title{
RESEARCH COMMUNICATIONS
}

9. Zhang, A., Wang, M. and Zhuo, P., Unc-51 like autophagy activating kinase 1 accelerates angiotensin II-induced cardiac hypertrophy through promoting oxidative stress regulated by NRF-2/HO-1 pathway. Biochem. Biophys. Res. Commun., 2019, 509, 32-39.

10. Volz, H. C. et al., HMGB1 is an independent predictor of death and heart transplantation in heart failure. Clin. Res. Cardiol., 2012, 101, 427-435.

11. Shen Lijuan, L. S., Yonghua, Z., Qingmin, X., Lan, L. and Chungang, Z., Expression and effect of HMGB1 and its inflammatory signaling pathway in rat model of DCM. Chongqin Yixue, 2017, 46, 1457-1462.

12. Rose, N. R., Myocarditis: infection versus autoimmunity. J. Clin. Immunol., 2009, 29, 730-737.

13. Eriksson, U., Kurrer, M. O., Schmitz, N., Marsch, S. C., Fontana, A., Eugster, H. P. and Kopf, M., Interleukin-6-deficient mice resist development of autoimmune myocarditis associated with impaired upregulation of complement C3. Circulation, 2003, 107, 320-325.

14. de Souza, A. W., Westra, J., Limburg, P. C., Bijl, M. and Kallenberg, C. G., HMGB1 in vascular diseases: its role in vascular inflammation and atherosclerosis. Autoimmunity Rev., 2012, 11, 909-917.

15. Nair, A. R., Ebenezer, P. J., Saini, Y. and Francis, J., Angiotensin II-induced hypertensive renal inflammation is mediated through HMGB1-TLR4 signaling in rat tubulo-epithelial cells. Exp. Cell Res., 2015, 335, 238-247.

16. Tang, D., Shi, Y., Kang, R., Li, T., Xiao, W., Wang, H. and Xiao, $\mathrm{X}$., Hydrogen peroxide stimulates macrophages and monocytes to actively release HMGB1. J. Leukocyte Biol., 2007, 81, 741-747.

17. Wu, Y., Zhang, K., Zhao, L., Guo, J., Hu, X. and Chen, Z., Increased serum HMGB1 is related to oxidative stress in patients with atrial fibrillation. J. Int. Med. Res., 2013, 41, 1796-1802.

18. Shen, L. J., Lu, S., Zhou, Y. H., Li, L., Xing, Q. M. and Xu, Y. L., Developing a rat model of dilated cardiomyopathy with improved survival. J. Zhejiang Univ. Sci. B, 2016, 17, 975-983.

19. Handa, N., Magata, Y., Mukai, T., Nishina, T., Konishi, J. and Komeda, M., Quantitative FDG-uptake by positron emission tomography in progressive hypertrophy of rat hearts in vivo. Ann. Nucl. Med., 2007, 21, 569-576.

20. Stegger, L. et al., Monitoring left ventricular dilation in mice with pet. J. Nuclear Med., 2005, 46, 1516-1521.

21. Gava, F. N. et al., Doxorubicin induced dilated cardiomyopathy in a rabbit model: an update. Res. Vet. Sci., 2013, 94, 115-121.

22. Lu, D. et al., Knockdown of cytochrome p450 2E1 inhibits oxidative stress and apoptosis in the $\mathrm{cTnT}(\mathrm{R} 141 \mathrm{~W})$ dilated cardiomyopathy transgenic mice. Hypertension, 2012, 60, 81-89.

23. Iqbal, N., Wentworth, B., Choudhary, R., Landa Ade, L., Kipper, B., Fard, A. and Maisel, A. S., Cardiac biomarkers: new tools for heart failure management. Cardiovasc. Diagn. Ther., 2012, 2, $147-164$.

24. Anand, I. S. et al., C-reactive protein in heart failure: prognostic value and the effect of valsartan. Circulation, 2005, 112, 14281434.

25. Okabe, K., Teneligliptin attenuated AngII-induced cardiac hypertrophy by inhibiting NOX4-HDAC4 axis. J. Card. Fail., 2017, 23, S56.

26. Willenheimer, R., Left ventricular remodelling and dysfunction. Can the process be prevented? Int. J. Cardiol., 2000, 72, 143150 .

27. Chintalgattu, V. and Katwa, L. C., Role of protein kinase C-delta in angiotensin II induced cardiac fibrosis. Biochem. Biophys. Res. Commun., 2009, 386, 612-616.

28. Hantson, P., Mechanisms of toxic cardiomyopathy. Clin. Toxicol., 2019, 57, 1-9.

29. Li, H. et al., Regulator of $\mathrm{G}$ protein signaling 5 protects against cardiac hypertrophy and fibrosis during biomechanical stress of pressure overload. Proc. Natl. Acad. Sci. USA, 2010, 107, 1381813823.

30. Ulloa, L. and Messmer, D., High-mobility group box 1 (HMGB1) protein: Friend and foe. Cytokine Growth Factor Rev., 2006, 17, 189-201.

31. Scaffidi, P., Misteli, T. and Bianchi, M. E., Release of chromatin protein HMGB1 by necrotic cells triggers inflammation. Nature, 2002, 418, 191-195.

32. Vande Walle, L., Kanneganti, T. D. and Lamkanfi, M., HMGB1 release by inflammasomes. Virulence, 2011, 2, 162-165.

33. Haudek, S. B., Taffet, G. E., Schneider, M. D. and Mann, D. L., TNF provokes cardiomyocyte apoptosis and cardiac remodeling through activation of multiple cell death pathways. J. Clin. Invest., 2007, 117, 2692-2701.

ACKNOWLEDGMENTS. This research was supported by the Jiangsu Province TCM Leading Talents Training Object Project and the Wuxi Medical Outstanding Talents Cultivation Project (JCRCPY005), China. Animal protocols were approved by the Animal Care and Use Committee of the Institute of Key Laboratory on Technology for Parasitic Disease Prevention and Control, Ministry of Health, China. Animal experiments were in compliance with the Guide for the Care and Use of Laboratory Animals by the Chinese Ministry of Science and Technology. The datasets generated and analysed in the present study are available with the corresponding author upon request.

Received 17 March 2020; revised accepted 19 September 2020

doi: $10.18520 / \mathrm{cs} / \mathrm{v} 119 / \mathrm{i} 11 / 1838-1845$

\section{Effect of water quality on caddisflies (Trichoptera) in Kallada river, Kerala, India}

\author{
Dani Benchamin*, R. Sreejai and Beena S. Kurup \\ Zoology Research Centre, St Stephen's College, University of Kerala, \\ Pathanapuram 689 695, India
}

The caddisflies (Trichoptera) constitute a significant water quality marker group because of their taxonomic richness, ecological diversity, and abundance in virtually all freshwater ecosystems. In this study, caddisflies were collected for an evaluation of the water quality in Kallada river, South, India. Samples collected during the pre-monsoon season were identified at the family level. In total, more than 4500 specimens were identified as belonging to five different taxa. These sensitive species have typically been restricted to non-polluted water bodies. The dominant family at stations S1, S2, S3 and S4 was determined to

*For correspondence. (e-mail: dani.gethsemane@gmail.com) 
be Hydropsychidae, whereas the dominant family at S5 was found to be Philopotamidae. The upstream, midstream and downstream sites of Kallada River show drastic differences among caddisfly assemblages. The lack of caddisflies in the midstream and downstream areas is due to anthropogenic interferences and mixing of seawater with freshwater within these low-altitude regions. Other sources of pollution, including bridge construction, urbanization and fishing both midstream and downstream are likely reasons for the fundamental changes in the composition of caddisfly assemblages observed in these areas.

Keywords: Caddisflies, freshwater habitats, Kallada, Trichoptera, water quality.

CADDISFLIES are aquatic insects known for their casebuilding and net-spinning behaviours. They are found mainly in freshwater habitats around the globe ${ }^{1}$. Based on recent studies, caddisflies can be used as an indicator species for identifying areas with freshwater pollution. Hydropsychidae is a family of widely distributed net-spinning caddisflies which use their nets for filterfeeding. In a lotic ecosystem, such nets are chief ecosystem engineering structures that can increase the delivery of food particles, control sediment erosion and allow an obtainable habitat to be developed for other insects. Caddisflies are egg-laying insects; the females normally laying between 30 and 1000 eggs placed in a layer encased in a sticky polysaccharide cover called 'spumaline' as a defence against predators ${ }^{2}$. For this, different plant parts, soil, pebbles and small mollusk shells are used as the major constituents ${ }^{3}$.

Freshwater macroinvertebrates are the most frequently used fauna for biomonitoring of aquatic systems worldwide. Their records help in evaluating the quality of local biodiversity ${ }^{4}$. Freshwater ecosystems are a refuge to many aquatic animals and plants. Regrettably, rivers have long been used for the dumping of waste ${ }^{5}$, resulting in a physical disturbance of riverbeds, spatial river-flow redistribution, water clogging and different types of pollution, generating further stress on these vulnerable ecosystems ${ }^{6}$. The present study aims to assess the diversity of caddisflies community and the possible effects of water quality on caddisflies found in Kallada river, Kerala, which flows through Thenmala, Punalur, Pathanapuram, Kadapuzha and Koivila before ending at Ashtamudi Lake in southern India.

Kallada River originates from the Kulathuppuzha slopes of the Western Ghats (Figure 1). The sampling sites chosen were Thenmala (TM), Urukunnu (UK), Punalur (PL), Pattazhy (PY), West Kallada (WK) and Koivila (KV). The caddisflies and water samples were collected from each site. Thenmala and Urukunnu are the upstream locales. Thenmala is a part of the Shendurney Wildlife Sanctuary. The trees of Shendurney line up on both sides of this site. Anthropogenic activities are pro- hibited in this site by the forest and irrigation authorities. The midstream sites are Punalur and Pattazhy. Punalur is an urban territory where contamination is exceptionally high. The Tourism Department has constructed a Bathing Ghat here for pilgrims. Pattazhy is a rural area with less contamination. The downstream sites, West Kallada and Koivila are the estuarine parts of Kallada River. These stations are the widest part of the river before it arrives at the Ashtamudi estuary.

For water-quality analysis, samples were collected in 11 labelled plastic containers and taken to the research facility for further examination. Various parameters such as temperature, $\mathrm{pH}$, dissolved oxygen, free $\mathrm{CO}_{2}$, conductivity, total alkalinity, total hardness, potassium and sodium were determined. Mercury glass thermometer $\left(0^{\circ}-600^{\circ} \mathrm{C}\right)$ was used to record water temperature. The $\mathrm{pH}$ and electrical conductivity were measured using a portable analyser Systronics. All other water quality parameters such as sodium, potassium, dissolved oxygen (DO), free carbon dioxide, total hardness and total alkalinity were analysed according to the standard proto$\mathrm{col}^{7}$.

Caddisflies larvae were collected using a D-ring dip net and Surber sampler, as described by USEPA ${ }^{8}$. This sampler helps collect benthic fauna present in the sediments. The sampling process was consistently disseminated over all reachable freshwater habitats, including sand, stones, logs, macrophytes and different substrates. Bountiful aquatic habitats in Kallada River were explored to collect the highest possible richness of Caddisflies. For this in addition to the previously mentioned examining techniques, larvae were handpicked from logs and stones. The number of samples collected from each sampling stations was one from 1541 - Thenmala, 1224 - Urukunnu, 348 - Punalur, 1605 - Pattazhy, 15 - West Kallada and 0 - Koivila (Figure 2). Caddisflies were then identified using the standard key ${ }^{9}$.

Various biological indices such as Pielou's evenness index $^{10}$, Margalef's richness index ${ }^{11}$, Shannon-Weiner index $^{12}$, Simpson's dominance index ${ }^{13}$ and Menhinick index ${ }^{14}$ were used for data analysis. Pearson correlation ( $r$ ) was applied to analyse the relationship between the collected invertebrates density and water quality parameters (Figure 3). From the point of view of monitoring the water quality of Kallada River, six sites were consistently sampled in the pre-monsoon season from February to May 2019 (Table 1). Regular monthly sampling was undertaken between 8:00 and 10:00 a.m. at each site throughout the study period.

More than 4733 caddisflies were identified in this study. Five families, viz. Hydropsychidae, Philopotamidae, Rhyacophilidae, Psychomyiidae and Limnephilidae were present in the sampling sites Thenmala, Urukunnu, Punalur, Pattazhy and West Kallada. However, they were absent in Koivila (the region where freshwater mixes with estuarine water). Caddisflies community was present 


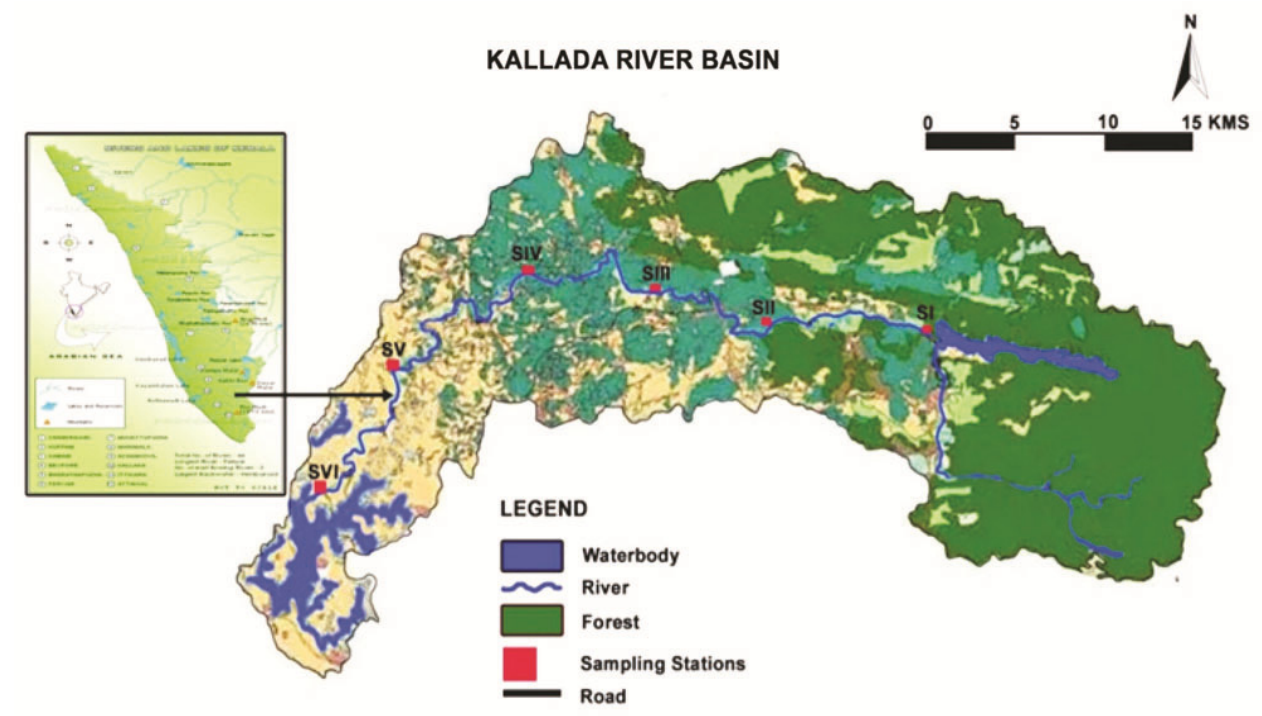

Figure 1. Location of study area in Kerala, India and sampling sites (S1-S6). (Direction of river flow is east to west.)

Table 1. Geographical characteristics of six sites in Kallada river, Keralal, India

\begin{tabular}{lccccl}
\hline Sites & Site code & Latitude & Longitude & Altitude $(\mathrm{m})$ & Anthropogenic interferences \\
\hline Thenmala & TM & 8.957740 & 77.065018 & 104 & Domestic activities, cattle farming \\
Urukunnu & UK & 8.985344 & 77.033527 & 47 & Domestic activities, cattle farming \\
Punalur & PL & 9.019580 & 76.922699 & 30 & Bridge construction, fishing, sewage, urbanization \\
Pattazhy & PY & 9.080699 & 76.797195 & 42 & Bridge construction \\
West Kallada & WK & 9.0116047 & 76.6068273 & 10 & Fishing, bridge construction, urbanization \\
Koivila & KV & 8.9962496 & 76.5783604 & 20 & Fishing, bridge construction, urbanization \\
\hline
\end{tabular}

Table 2. Mean value of physico-chemical characteristics of water in Kallada river

\begin{tabular}{lcc}
\hline Parameters & Mean $\pm \mathrm{SD}$ & Range \\
\hline Water temperature $\left({ }^{\circ} \mathrm{C}\right)$ & $25.5 \pm 0.547$ & $25-26$ \\
$\mathrm{pH}$ & $7.25 \pm 0.659$ & $7-8.26$ \\
Dissolved oxygen $(\mathrm{mg} / \mathrm{l})$ & $9.918 \pm 2.032$ & $6.9-12.50$ \\
$\mathrm{CO}_{2}(\mathrm{mg} / \mathrm{l})$ & $5.166 \pm 0.752$ & $4-6$ \\
Conductivity $(\mu \mathrm{S} / \mathrm{cm})$ & $55.771 \pm 17.420$ & $33.2-75.73$ \\
Total alkalinity $(\mathrm{mg} / \mathrm{l})$ & $20 \pm 7.694$ & $12-30$ \\
Total hardness $(\mathrm{mg} / \mathrm{l})$ & $101.333 \pm 156.003$ & $12-412$ \\
$\mathrm{~K}(\mathrm{mg} / \mathrm{l})$ & $95.293 \pm 142.983$ & $1.76-280.75$ \\
$\mathrm{Na}(\mathrm{mg} / \mathrm{l})$ & $179.163 \pm 270.058$ & $4.01-562.0$ \\
\hline
\end{tabular}

throughout the pre-monsoon season; the upstream sites were the richest with maximum density (2765) followed by the midstream (1953) and downstream (15) sites (Figure 2). Hydropsychidae family was dominant in all six sites. Family Philopotamidae family was the main dominant taxa followed by Hydropsychidae at station Urukunnu, Pattazhy and West Kallada. At TM and PL, Hydropsychidae and Limnephlidae families were the prevailing taxa.

The hydro-biology of water is a significant factor that influences the abundance of benthic macroinvertebrate fauna in a community. The $\mathrm{pH}$ of water at sites UK, WK and $\mathrm{KV}$ indicated its alkaline nature; the $\mathrm{pH}$ of the downstream sites was high in contrast with the other five sites. The high DO content in station PY was perceived as a strong water current ${ }^{15}$. The alkalinity and hardness showed negative correlation with caddisflies density. Subsequently, the lowest concentration of these parameters may have increased the abundance of species in stations TM, UK and PY. The concentration $\mathrm{Na}$ and $\mathrm{K}$ influences the caddisflies density in the course of Kallada River and is one of the basic control parameters (Table 2). Related documentations from Germany ${ }^{16}$ and New Zealand $^{17}$ underpin this occurrence for different freshwater systems.

Caddisflies density showed a significant positive correlation with DO (Table 3). The richness in diversity of caddisflies was maximum in stations TM, UK and PY, presumably because of the higher content of $\mathrm{DO}^{18}$. Low density of caddisflies was recorded in midstream and downstream stations such as PL, WK and KV. The richness of caddisflies were maximum upstream presumably because of suitable environmental factors, presence of logs, stones and different substrates at the bottom, and shallow depth (Table 2) ${ }^{15,19}$. The absence of Trichoptera in station $\mathrm{KV}$ was likely because of greater depth, mixing of seawater in the downstream. Furthermore, increased anthropogenic interference such as fishing vessels across 


\section{RESEARCH COMMUNICATIONS}

Table 3. Correlation among limnological parameters and caddisflies density

\begin{tabular}{|c|c|c|c|c|c|}
\hline Limnological parameters & Hydropsychidae sp. & Philopotamidae sp. & Rhyacophilidae sp. & Psychomyiidae sp. & Limnephilidae sp. \\
\hline Water temperature $\left({ }^{\circ} \mathrm{C}\right)$ & -0.333 & -0.3088 & -0.4104 & -0.4289 & -0.4154 \\
\hline $\mathrm{pH}$ & -0.4866 & -0.4862 & -0.5033 & -0.468 & -0.5473 \\
\hline DO (mg/l) & 0.4193 & 0.4385 & 0.3238 & 0.3364 & 0.2638 \\
\hline $\mathrm{CO}_{2}(\mathrm{mg} / \mathrm{l})$ & -0.8332 & -0.8415 & -0.798 & -0.7716 & -0.8054 \\
\hline Conductivity (NTU) & -0.1729 & -0.1401 & -0.3049 & -0.3095 & -0.3541 \\
\hline Alkalinity (mg/l) & -0.8437 & -0.8349 & -0.8629 & -0.8736 & -0.8486 \\
\hline Hardness (mg/l) & -0.6762 & -0.6814 & -0.6606 & -0.6409 & -0.6709 \\
\hline $\mathrm{K}(\mathrm{mg} / \mathrm{l})$ & -0.8161 & -0.8214 & -0.7944 & -0.7659 & -0.8124 \\
\hline $\mathrm{Na}(\mathrm{mg} / \mathrm{l})$ & -0.8117 & -0.8167 & -0.7904 & -0.7619 & -0.8086 \\
\hline
\end{tabular}

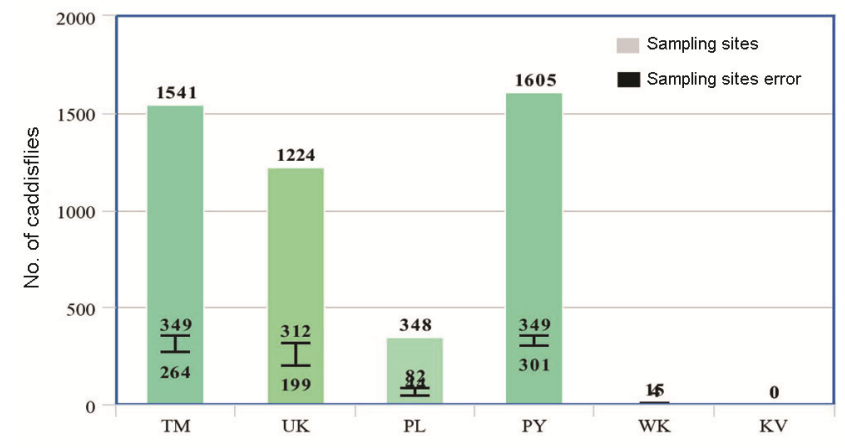

Figure 2. Caddisflies fauna in different sampling sites of Kallada river.

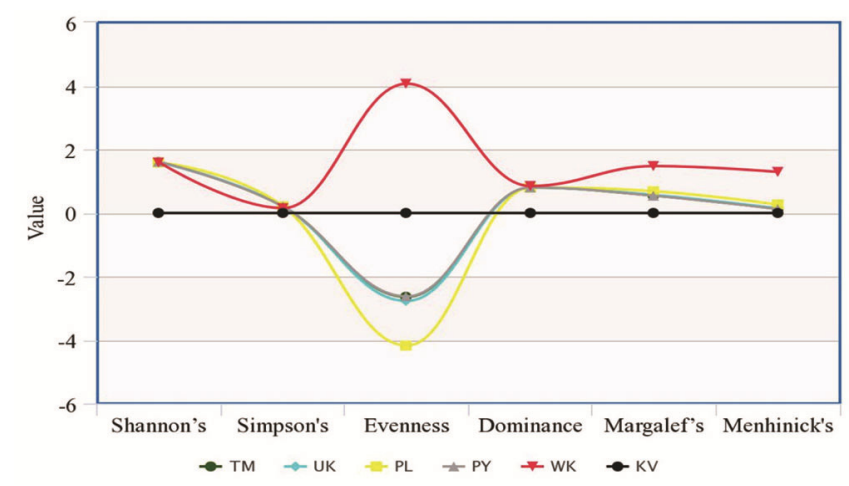

Figure 3. Taxonomic indices of caddisflies community in Kallada river.

the river, sewage disposal, bridge constructions, and various small scale industries at this region causes the absence of appropriate substratum of caddisflies community $^{15,20}$.

The Kallada River is a precious pool of caddisflies community. Since information about caddisflies from Kerala is lacking up to now, the identified caddisflies in the Kallada River are invaluable to advance extra examinations in Kerala. Generally, further taxonomic assessments should be done for the identification of the Trichoptera to species level. The presence and absence of different caddisflies taxa in polluted and non-polluted zones of the Kallada River indicate that they could be uti- lized as potential bioindicators for the assessment of water quality.

1. Holzenthal, R. W., Trichoptera (Caddisflies). In Encyclopedia of Inland Waters, Elsevier, Oxford, 2009, pp. 456-467.

2. John, C. M., Paul, B., Frandsen, Wolfram, G. and Jessica, A. T., Diversity and ecosystem services of Trichoptera. Insects, 2019, 10, $1-27$.

3. Sipahiler, F., New Rhyacophila (Trichoptera Rhyacophilidae) species from France and Spain. Aquat. Insects, 2000, 22, 138-147.

4. Irfan, R. and Shakil, R., Impact of anthropogenic activities on water quality of Lidder River in Kashmir Himalayas. Environ. Monit. Assess., 2012, 185; doi:10.1007/s10661-012-2898-0.

5. Schmera, D., Effect of 'species weighting' on conservation status evaluation: a case study with light-traped adult caddisflies (Insecta: Trichoptera). Biodivers. Conserv., 2003, 12, 1175-1191.

6. Sergey, M. G., In Proceedings of the International Congress on River Basin Management, Antalya, Turkey, 2007, pp. 464-476.

7. APHA, Standard Methods for the Examination of Water and Waste Water - 23rd Edition, American Public Health Association, Washington, DC, USA, 2007.

8. USEPA, National Rivers and Streams Assessment. Field Operations Manual, US Environmental Protection Agency, Washington, DC, USA, 2007, EPA-841-B-07-009.

9. Wallace, I., The Beginner's Guide to Caddis (Order Trichoptera) by Keeper of Invertebrate Zoology, National Museums and Galleries on Merseyside, William Brown Street, Liverpool, L3 8EN, Illustrated by Phil Wilkins (7607) Peregrine Productions, The Summerhouse, Orford Road, Tunstall, Suffolk IP12 2JA, 2003, vol. 62, pp. 15-26.

10. Pielou, E. C., The measurement of diversity in different types of biological collections. J. Theor. Biol., 1966, 13, 131-144.

11. Margalef, R., Perspectives in Ecological Theory, University of Chicago Press, Chicago, USA, 1968, p. 111.

12. Shannon, C. E. and Wiener, W., The Mathematical Theory of Communication, University of Illinois Press, Urbana, USA, 1949, p. 177.

13. Simpson, E. H., Measurement of diversity. Nature, 1949, 163, 688.

14. Menhinick, E. F., A comparison of some species-individuals diversity indices applied to samples of field insects. Ecology, 1964, 45, 859-861.

15. Arnab, B., Indrani, S., Siddartha, D. and Sheela, R., Community structure of benthic macroinvertebrate fauna of river Ichamati, India. J. Threat. Taxa, 2018, 10, 2044-12055.

16. Braukmann, U. and Dirk, B., Conceptual study - an improved method to assess acidification in German streams by using benthic macroinvertebrates. Limnologica, 2004, 344, 433-450.

17. Barrie, M. F., Paul, A. G., Chris, D. C. and Karyne, M. G., Multiple indicators reveal river plume influence on sediments and 
benthos in a New Zealand coastal embayment. N.Z. J. Mar. Freshw. Res., 2007, 41, 13-24.

18. Odiete, W. O., Environmental physiology of animals and pollution. Diversified Resources, Lagos, Nigeria, 1999, pp. 220-246.

19. Roy, S. and Gupta, A., Molluscan diversity in river Barak and its tributaries, Assam, India. Assam Univ. J. Sci. Technol.: Biol. Environ. Sci., 2010, 5, 109-113.

20. Leprieur, F. O., Beauchard, S., Blanchet, T., Oberdorff, S and Brosse, Fish invasions in the world's river systems: when natural processes are blurred by human activities. PLoS Biol., 2008, 6, 28.

Received 30 June 2020; accepted 4 October 2020

doi: $10.18520 / \mathrm{cs} / \mathrm{v} 119 / \mathrm{i} 11 / 1845-1849$

\section{Heavy metal contamination in soils and crops irrigated with lakes of Bengaluru}

\author{
N. Hamsa* and N. B. Prakash \\ Department of Soil Science and Agricultural Chemistry, \\ University of Agricultural Sciences, GKVK, Bengaluru 560 065, India
}

Soils and vegetable crops being irrigated with water from six lakes in Bengaluru, India were analysed using ICP-OES for heavy metals and characterized based on the permissible limits of the European Union (EU) and the Indian Standards (IS). Chromium, nickel and lead content in the soils ranged from 89.36 to $145.21,0.90$ to 19.17 and below detection limit to $0.31 \mathrm{mg} \mathrm{kg}^{-1}$ respectively. Among the total soil samples collected, $15 \%, 22 \%, 20 \%, 23 \%, 15 \%$ and $33 \%$ of the samples exceeded permissible limits of EU and IS for cadmium under Margondanahalli, Yele Mallappa Shetty, Hoskote, Varthur, Byramangala and Jigani lake respectively. All the crop samples analysed exceeded the $\mathrm{EU}$ standards for $\mathrm{Cr}, 25 \%$ for $\mathrm{Ni}$, and none for $\mathrm{Cd}$ and $\mathrm{Pb}$.

Keywords: Heavy metals, lake water, soil contamination, standard permissible limits, vegetable crops.

LAKES were once important water resources for household needs, animal husbandry and agriculture. Bengaluru, Karnataka, South India had 280-285 lakes, many of which have been encroached by slums and private parties, dried up, leased out by Government organizations; today only 17 lakes exist. Unlike other cities, lakes in and

*For correspondence. (e-mail: hamsanraj@gmail.com) around Bengaluru have become part of the city drainage system that drains untreated and partially treated domestic sewage and industrial effluents from a number of small-scale units like garment factories, electroplating industries, distilleries, etc. The unscientific disposal of wastewater has caused immense environmental problems not only to the aquatic environment but also to humans worldwide $^{1}$. This problem has intensified during the last few decades and the situation has become alarming in India $^{2}$. The farmers in and around Bangalore use water from the lakes for cultivation of crops and in particular, vegetables. Soils receiving water from these lakes accumulate heavy metals to varying degrees depending on their concentration in water and the frequency of irrigation. The contamination of lake water with heavy metals leads to their accumulation in the sediments. When farmers use the sediments in agricultural fields as a common practice, the heavy metals accumulate in agriculture soils and pose serious problems. Wastewater irrigation may lead to the accumulation of heavy metals in agriculture soils and plants ${ }^{3}$. The heavy metals are absorbed by crops along with other essential plant nutrients. Heavy metals are non-biodegradable and thermostable, and thus readily accumulate to toxic levels ${ }^{4}$. Contamination of soils and crops with these metals may have adverse effects on soils, plants, animals and humans. Food safety issues and potential health risks make this one of the serious environmental concerns ${ }^{5}$. Ultimately different crops grown in these sites irrigated with contaminated lakes have shown uptake of heavy metals that make them unfit for consumption ${ }^{6}$. The present study aims to assess the extent of heavy-metal contamination of soils irrigated with lake water in Bengaluru urban and peri-urban areas.

Bengaluru is located in the southern part of Karnataka. Out of 17 lakes in Bengaluru, six were selected for the present study-Margondanahalli, Yele Mallapa Shetty (YMS), Hoskote Doddakere, Varthur, Byramangala and Jigani (Figures 1 and 2).

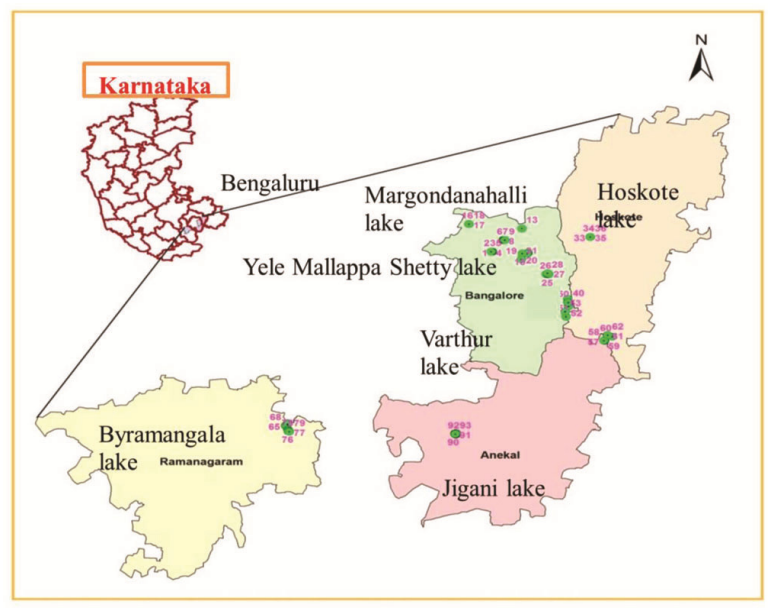

Figure 1. Soil and crop sampling sites irrigated with water from different lakes in Bengaluru, India. 